\title{
THE ESSENTIALS OF AN ADEQUATE HEALTH PROGRAM
}

"We are apt to forget that our people are our greatest resource. Their health is indeed America's primary concern."

$$
\text { -William 0. Douglas* }
$$

High as the quality of American health care may be, there is far from enough of it and many are unable to make use of what there is. The same may be said of fur coats, diamonds, or perhaps even automobiles. But a lack of luxury items, unlike an absence of adequate health care, will not produce a serious deterioration of human resources. In this respect, protection of health is like education, ${ }^{1}$ which has long been recognized as essential to the full development of an individual's capabilities. ${ }^{2}$ Both poor health and poor education impose severe losses on society in general as well as on the individuals who are concerned. ${ }^{3}$

The "free market" in health services has done nothing but perpetuate these losses. Even opponents of a national health program must concede that many Americans receive grossly inadequate health care. Morbidity and mortality rates and the amounts of care received vary widely according to income group, racial strain, and geographic area. 4 For example, the wealthy

* Dovglas, Being an American 146-7 (1948).

1. See, e.g., A Bill for the More General Diffusion of Krowledge, 1779, in 2 Tuv Writings of Thosias Jefrerson 220 (Ford ed. 1893), and a discussion of the Bill in a letter from Jefferson to George Ticknor, in $10 \mathrm{id}$. at 94, 95-6; and see Notes on the State of Virginia, in 3 id. at 254.

2. For the general proposition that a basic goal of a democratic society is to assure every person an equal opportunity to develop fully his personality and capabilities, see, e.g., Barker, Reflections on Government 190-4 (1942) ; Fromar, Escape from FreedoM 270-3 (1941). And see Lasswell \& McDougal, Legal Education and Public Policy: Professional Training in the Public Interest, 52 YALE L.J. 203, 212, 224 (1943).

3. In this connection, note the economic bill of rights formulated by President Roosevelt. Included were:

"The right to adequate medical care and the opportunity to achieve and enjoy good health;

"The right to adequate protection from the economic fears of . . . sickness. ..."

"The right to a good education."

Annual Message of the President to Congress, Jan. 11, 1944, The Selected Addresses of Frankdin D. Roosevelt 387, 396 (1946). See also President Truman's Messages to Congress: Nov. 19, 1945, H.R. Doc. No. 380, 79th Cong., 1st Sess. (1945); March 19, 1947, H.R. Doc. No. 261, 80th Cong., 1st Sess. (1947) ; April 22, 1949, SEN. Doc. No. 59, 81 st Cong., 1st Sess. (1949). This Comment is concerned only with the problem of providing adequate medical care. For discussion of protection against the loss of carnings during illness, see, e.g., Falk, Reed \& Sanders, Some Problems in the Formulation of a Disability Insurance Program, 6 Law \& Contemp. Prob. 645 (1939).

4. Two other sets of statistics are frequently cited in controversies over the state of the nation's health. Proponents of a national health care plan point to draft rejection statistics, which show that 40 per cent of the registrants examined were unfit for military service. See Wartime Health and Education, SEN. SubcomsirteE REp. No. 3, 80th Cong, 2d Sess. (1947), reprinted in Hearings before a Subcommittee of the Committec on Labor and Public Welfare on S. 545 and S. 1320, 80th Cong., 1st Sess. 72-6 (1947); for a com- 
receive as much as 600 per cent more care than the poor, even though the poor spend a larger proportion of their income for health services. ${ }^{.}$One

plete compilation, see Hollingsworth, Krear \& Baney, Miedrcal Cane and Costs mi Rezation to Fayimy Incoare: A Statistical Source Book (Federal Security Agency, Bureau of Research and Statistics, Memorandum No. 51) 129-38 (1947) (hereinafter cited as BuMEM 51). Breakdowns of these figures certainly indicate the need for better health care. But many of the causes for rejection were either non-medical or only in small part attributable to lack of medical facilities. See Bacharass \& Mierrass, The Issue of CoMpulsory Health Insurance 113-14 (1948).

On the other hand, those who attempt to emphasize the adequacy of health care in the United States frequently cite the health position of the United States ais a zis other nations. See, e.g., id. at 15-17. These statistics show that the United States is frequently near the top, but does not lead, in any series of statistics bearing on health. In 1939-10 the United States was fifth in life expectancy at birth (but only ninth at age 20, twclith at age 40, and thirteenth at age 60). Thosipson \& Wherptos, Estrasntes of Future Population of the United States 1940-2000 (National Resources Planning Board) 7 (1943), reprinted in Bulfesr 51 at 66. But if the health position of the United States were proportional to its wealth, it would far outdistance all other nations in these statistics.

5. While a higher incidence of sickness has been found among the rich than the poor (in ratio of about $1: 1.4$ ), the difference is insufficient to explain the difierences in receipt of care among income groups. FaLK, KIEAr \& SrNar, TuE INCroEnce of ILLNESS and the Receipt and Costs of Miedical Care Ayrong Represemtative Fasulmes 237 (1933). The following chart will demonstrate this:

Number of specifed services received per 1,000 persons, by family income group, in a 12 month period, 1928-31:

\begin{tabular}{|c|c|c|c|c|c|}
\hline \multirow[b]{2}{*}{ Item } & \multicolumn{5}{|c|}{ Income grotlp } \\
\hline & $\begin{array}{c}\text { Less } \\
\text { than } \\
\$ 1,200\end{array}$ & $\begin{array}{r}\$ 2,000- \\
2,909\end{array}$ & $\begin{array}{l}\$ 5,000 \\
0,000\end{array}$ & $\begin{array}{l}\$ 10,000 \\
\text { or more }\end{array}$ & $\begin{array}{l}\text { Eslimoled } \\
\text { number of } \\
\text { serriees } \\
\text { reeded }\end{array}$ \\
\hline \multirow[t]{2}{*}{ Illnesses per 1,000 persons } & 802.5 & 828.9 & 989.7 & $1,111.5$ & 936.3 \\
\hline & \multicolumn{5}{|c|}{ Services per 1,000 persons } \\
\hline $\begin{array}{l}\text { Hospitalized cases (1 day or longer) } \\
\text { Days of hospital care } \\
\text { Physicians' home, office and clinic calls } \\
\text { Dental care (persons over } 3 \text { years of age) } \\
\text { Health examinations } \\
\text { Immunizations } \\
\text { Refractions or glasses } \\
\text { Home and office calls by secondary and }\end{array}$ & $\begin{array}{r}59.4 \\
1,368.7 \\
1,931.9 \\
117.9 \\
83.2 \\
68.5 \\
24.5\end{array}$ & $\begin{array}{r}59.4 \\
884.0 \\
2,296.7 \\
247.5 \\
69.1 \\
50.9 \\
39.6\end{array}$ & $\begin{array}{r}79.3 \\
896.0 \\
3,621.4 \\
446.0 \\
121.7 \\
84.3 \\
89.6\end{array}$ & $\begin{array}{r}98.0 \\
1,270.4 \\
4,734.4 \\
622.0 \\
234.0 \\
120.2 \\
159.7\end{array}$ & $\begin{array}{r}113.5 \\
3,752.5 \\
5,649.5 \\
1,000.0 \\
941.9 \\
185.3 \\
175.0\end{array}$ \\
\hline sectarian practitioners & 154.6 & 230.4 & 459.0 & 569.2 & \\
\hline
\end{tabular}

FaLR, KIEMr \& SinaI, op. cit. supra, at 124, 283, reprinted in BuMrear 51 at 106. (Footnotes omitted.)

The difference is also demonstrated by the statisties on the percentage of illness receiving any health services among different income groups:

$\begin{array}{ccccccc} & \text { Less than } & \$ 1,200- & \$ 2,000- & \$ 3,000- & \$ 5,000- & \$ 10,000 \\ \text { All incomes } & \$ 1,200 & 1,999 & 2,999 & 4,999 & 9,999 & \text { or more } \\ 77.6 & 66.5 & 75.0 & 80.4 & 81.4 & \$ 9.0 & 92.7\end{array}$

FALK, KIEM \& SiNAI, op. cit. supra, at 282, reprinted in BuAfear 51 at 107.

6. In 1941, families and single consumers with incomes less than $\$ 500$ spent an 
recent study shows that death rates range from 13.0 per thousand annually in Maine to 8.2 in Utah $;^{7}$ another demonstrates that births outside of hospitals vary upwards from 6.7 per cent in the six New England states to 60.6 per cent in the four East South Central states. 8 The parents of a new-born Negro baby can expect its life to be ten years shorter than that of its white contemporary. $^{\circ}$ The odds that its mother will die in childbirth, compared with the same possibility for a white mother, are nearly three times as great. ${ }^{10}$

These disparities cannot be ascribed solely to a lack of adequate health care. Deficiencies in diet, housing and education are equally responsible, and specific remedies to repair these deficiencies would undoubtedly contribute to an improvement in national health. And at root, poor health,

average of 9.3 per cent of their money income for medical care; twith incomes from $\$ 500$ 999, 5.4 per cent; $\$ 1,000-1,499,5.1$ per cent; $\$ 1,500-1,999,5.0$ per cent; $\$ 2,000-2,999,4.2$ per cent; and those with incomes from $\$ 3,000-4,999$ spent an average of 4.1 per cent of their incomes for medical care. United States Bureav of Laror Statistics, Famity Spending and Saving in Wartine (H.R. Doc. No. 147A, 79th Cong., 1st Sess.) 71, 75 (1945), reprinted in BuMEA 51 at 154.

7. Number of Deaths and Crude Death Rates: United States, Each Division and State, 1940-44 in 25 United States Bureau of the Census, United States Vital Satistics: Spectal Reports, 1944, p. 18 (1947), reprinted in BuMEM 51 at 50.

8. Births by Person in Attendance, 1944, in 25 United States Buresu of trie Census, op. cit. supra note 7, at 37. Rural and urban differences in amount of care received are not quite as startling, but they are still significant:

Per cent of persons receiving specified items of care, by size of community, in a 12 month period, 1928-31:

\begin{tabular}{|c|c|c|c|c|c|c|c|}
\hline \multirow[b]{2}{*}{ Community } & \multirow{2}{*}{$\begin{array}{l}\text { Number } \\
\text { of } \\
\text { Persons }\end{array}$} & \multicolumn{6}{|c|}{ Per cent of Persons Receiving Care } \\
\hline & & $\begin{array}{c}\text { Any } \\
\text { Medical } \\
\text { Cate }\end{array}$ & $\begin{array}{l}\text { Physi- } \\
\text { cian }\end{array}$ & $\begin{array}{c}\text { Hospital } \\
\text { Care }\end{array}$ & $\begin{array}{l}\text { Dental } \\
\text { Care }\end{array}$ & $\begin{array}{c}\text { Eye } \\
\text { Care } \\
\text { and } \\
\text { Glasses }\end{array}$ & $\begin{array}{c}\text { Heallh } \\
\text { Examina- } \\
\text { lions and } \\
\text { Immintiza- } \\
\text { tions }\end{array}$ \\
\hline All Communitie & 38,668 & 61.6 & 47.9 & 5.8 & 21.2 & 3.8 & 11.4 \\
\hline $\begin{array}{l}\text { Cities of } 100,000 \text { or } \\
\text { more population }\end{array}$ & 14,518 & 64.0 & 48.2 & 7.1 & 26.7 & 4.6 & 9.8 \\
\hline $\begin{array}{l}\text { population } \\
\text { Towns of less than }\end{array}$ & 9,745 & 64.8 & 52.0 & 6.4 & 22.7 & 4.0 & 12.9 \\
\hline areas & 14,405 & 58.5 & 45.7 & 4.6 & 17.1 & 3.2 & 11.6 \\
\hline
\end{tabular}

BUMEM 51 at 103.

9. Life expectancy at birth, United States, 1942:

$\begin{array}{cccc}\text { White } & \text { Male } & \text { Female } \\ \text { Non-White } & \text { White } & \text { Non-White }\end{array}$

Metropolitan Life Insurance Company, Longevity of the American Pcople at Peak in 1942, Statistical Bulletin, April, 1944, p. 6, reprinted in BuMEM 51 at 64.

10. In 1944, the maternal death rate per 1,000 live births in the United States was 1.9 for whites and 5.0 for non-whites. Maternal Mortality by Age and Race, 1944, in 25 United States Bureau of the Census; op. cit. supra note 7, at 103, reprinted in BuMea 51 at 62. 
housing, diet and education are all largely attributable to inadequate purchasing power among low-income groups.

Eventually, national income may rise to a point where the lowest-income families are able and willing to purchase adequate health care. But such an increase in national income is a distant prospect. Moreover, measures to improve housing, diet and education operate slowly and incompletely on health. Neither approach meets the need for an immediate, direct attack on the health problem. For this reason, several bills were introduced in the first session of the Eighty-First Congress, each proffering a plan to improve the nation's health. ${ }^{11}$ In some respects these plans are in agreement. Generally, they propose to support and expand medical, dental and nursing educational institutions ;2 $^{\mathbf{1 2}}$ to increase appropriations for hospital construction $;^{\mathbf{1 3}}$ and to subsidize medical research and local public health units with federal funds. ${ }^{14}$ But they differ widely on the fundamental question of how to aid the individual in paying for the health care that he needs.

The Administration bill proposes a national insurance plan with fairly complete coverage, financed primarily through a federal employer-employee payroll tax, and administered on a federal-state-local basis. ${ }^{10}$ The Taft bill, at

11. Senator Hill, with Senators O'Conor, Withers, Aiken and Mforse, sponsored S. 1456, cited hereinafter as the Hill bill; Senator Taft, with Senators Smith and Donnell, sponsored S. 1581, cited hereinafter as the Taft bill; Senator Thomas (of Utah), with Senators Murray, Wagner, Pepper, Chavez, Taylor, MreGrath and Humphrey, sponsored S. 1679, cited hereinafter as the Administration bill; and Senator Flanders, with Senator Ives, sponsored $S$. 1970, cited hereinafter as the Flanders-Ives bill.

12. See Taft bill, Title VI, Pt. B, "Temporary Payments to Afedical Schools for Maintaining and Increasing Enrollment"; Administration bill, Title I, "Education of Health Personnel"; Flanders-Ives Bill, Title VII, "Assistance to Aredieal and Nursing Schools." For discussion of a long series of bills introduced in the House of Representatives to support and expand health care personnel education, see Hearings before a Subcommittee of the Committee on Interstate and Foreign Commerce on H.R. 4312 ond H.R. 4313 (Identical Bills) and H.R. 4918 and other Identical Bills, 81st Cong., 1st Sess. 325-456 (1949).

13. Taft bill, Title IV, "Amendments to Hospital Survey and Construction Act"; Administration bill, Title III, "Hospital Survey and Construction Amendments"; Flanders-Ives bill, Title VIII, §3(a), "Extension of Hospital Construction Program." For discussion of the bills introduced in the House of Representatives, see Hearings before a Stbcommittee of the Committee on Isterstate and Foreign Conmerce on H.R. 4312 and H.R. 4313 (Identical Bills) and H.R. 4918 and Other Identical Bills, S1st Cong., 1st Sess. 745-926 (1949).

14. Taft bill, Title V, "Local Public Health Units"; Administration bill, Title II, "Medical Research," Title VI, Pt. A, "Research in Child Life," Title IV, "Special Aid for Rural and Other Shortage Areas," and Title V, "Grants to States for State and Loeal Health Work"; Flanders-Ives bill, Title VIII, §4(a), "Local Public Health Units." For discussion of the bills introduced in the House of Representatives to increase medical research, see Hearings before a Subcommittee of the Commiltec on Interstate and Forcign Commerce on H.R. 4312 and H.R. 4313 (Identical Bills) and H.R. 4918 and Other Idertical Bills, 81st Cong., 1st Sess. 457-744 (1949). And for discussion of the bills introduced in the House of Representatives to aid local public health units, see id. at 927-995.

15. Administration bill, Title VII, "Prepaid Personal Health Insurance Benefits." 
the other extreme, would appropriate federal funds for health care for the needy only on a federal-state matching basis. ${ }^{10}$ Two other bills, seeking "the middle course,"17 would appropriate federal funds for the support of voluntary health insurance. ${ }^{18}$

These alternatives will be measured against their ability to meet two basic objectives: (1) satisfying the nation's requirements for additional health care personnel and facilities; and (2) creating effective demand which will enable persons to use the available services.

\section{The Problem of Supply}

\section{Personnel}

At present rates of training, annual increments to the supply of health care personnel will not meet minimum requirements. In the 12 states where concentration of health care personnel is greatest, one physician serves 667 persons. ${ }^{19}$ Assuming that this ratio is adequate, the United States would require 254,000 doctors in 1960 in order to attain it. ${ }^{20}$ Without government aid the nation will fall short of this goal by an estimated 20 per cent. ${ }^{21} \mathrm{By}$ the same measure, a 21 per cent shortage of dentists ${ }^{22}$ and a 29 per cent

16. Taft bill, Title II, "Grants in Aid for Extending Medical, Hospital, and Dental Services to Individuals Unable to Pay the Whole Cost Thereof; and for Other Purposes."

17. For a discussion of the proposal so denominated, see Heyman, The Health Issuc: A Middle Course, New York Times Magazine, March 6, 1949, pp. 10, 27-30.

18. For a discussion of the differences between these two proposals, see pp. 307-8 infra.

19. Ewing, Tene Nation's Health: A Ten Year Prograns 38 (1948). The average over the whole nation in 1940 was one effective physician for every 876 persons. Mort \& Roemer, Rural Healte and Medical Care 158 (1948).

20. Eving, op. cit. supra note 19, at 38. For an earlier estimate that an average of one practicing physician is required for every 742 persons, see LEE \& JONES, TUE FUNDAarentals of Good Medical Care 115 (1933). Using these estimates, the United States would need 229,000 practicing physicians in 1960 (assuming that the poptlation will be $170,000,000$ ).

But the higher Federal Security Administration estimate seems more valid today, considering the advances in medicine since 1933 , the trend toward specialization, and the likelihood that even in the 12 "best" states the total amount of care given is not more than is needed.

21. Assuming a desired ratio of one to 657 , the United States faccs a shortagc of 42,000 physicians by 1960 . EwIng, op. cit. supra note 19, at 38. Using the Lec-Jones ratio, the shortage would be 17,000 . Maximum government assistance to health care education can reduce the shortage only by 15,000 physicians. See EwING, op. cit. supra note 19 , at 40,46 . Consequently, under either estimate maximum government assistance is necessary.

22. Ewing estimates, on the basis of the 12-state ratio, that one dentist is needed for every 1,400 persons, and that on this standard 113,000 dentists will be required by 1960 . EwING, op. cit. supra note 19, at 38 . According to the Lee-Jones ratio of one to every 999 persons (LEE \& JonEs, op. cit. supra note 20, at 126) the United States would need approximately 160,000 dentists by 1960 . Present prospects point toward only 90,000 dentists by 1960. Hearings before a Subcommittee of the Committee on Interstate and For- 
shortage of nurses will result. ${ }^{23}$

In part, this shortage can be overcome by more effective utilization of existing personnel. Doctors, dentists and nurses today spend a part of their available time in idleness for want of patients. ${ }^{2 t}$ Creating more health care purchasing power would minimize this unnecessary waste of skills. Furthermore group practice, which utilizes personnel and facilities more effectively, should be encouraged. ${ }^{25}$ To thrive, these group prepayment plans must be removed from the choking restrictions of many state laws; $;^{30}$ and the antitrust laws must be vigorously invoked against the coercive opposition of organized medicine. ${ }^{27}$

eign Commerce on H.R. 4312 and H.R. 4313 (Identical Bills) and H.R. 4918 and Othcr Identical Bills, 81st Cong., 1st Sess. 327 (1949); EwING, op. cit. sipra note 19, at 38. Thus the maximum estimated shortage by 1960 will be 70,000 dentists, the minimum 5,000. The most liberal proposal for government aid to dental schools (see note 32 infra) apparently seeks to increase present prospects by 5,000 dentists. See Evrsig, of. cit. supra note 19, at 46. Thus either estimate demonstrates the need for maximum government assistance.

23. EWING, op. cit. supra note 19 , at 38 .

24. For a suggestion that there is "too much wastage of time" among the nation's physicians, see Cabot, The Lesson of the Rejectees, 31 Surver Grapmic 120, 121 (1942).

25. Goldnand, Public Miedical Care 173-8 (1945); Carot, The Patrent's DIlemara 31, 204 (1940); CoMrartiege on the Costs of Miepical Care, aledical Cane fos the Amirrican People 109 (1933). See Rorear, Private Grout Cimics 11-12 (1931), for a definition of private group practice. For an excellent summary of the advantages of group practice of medicine, see CLARK \& CLARE, ObGanization and Adsomistration or Grout Medical Practice (Twentieth Century Fund and Good Will Fund) \&-11 (1941).

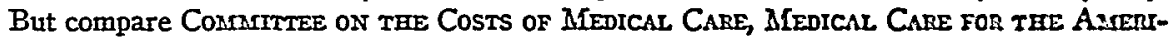
CAN People 152, 155, 159-62 (1933) (minority report); Asrericax liedical Assocthtion, Bureau of Miedical Econonics, Grour Practice (1933); Editorial, $99 \mathrm{~J}$. Asr. MED. AssN. 1950, 1952 (1932) (group practice, as advocated in the report of the Committee on the Costs of Medical Care, is "socialism, and communism-inciting to revolution.")

26. For an analysis of how these state laws hamper the growth of voluntary health plans, see Comment, Group Health Plans: Some Legal and Economic Aspects, 53 YarE L.J. 162, 166-75 (1943).

27. The antitrust laws have been invoked against the American Mredical Association. American Medical Association v. United States, 130 F.2d 233 (D.C. Cir. 1942), aff'd, 317 U.S. 519 (1943) (criminal conviction of the AMIA and the Washington, D.C. Aredieal Society for conspiracy to restrain trade in the District of Columbia by threatening to blacklist hospitals which allowed doctors who practiced through the Group Health Association to use their facilities). A similar suit is now pending. United States v. Oregon County Mredical Society, civil complaint filed Oct. 18, 1948, '48-'51 CCH TRADE REg. REP. I 61,160 (1948) (alleging a conspiracy among the Oregon medical societies to prevent prepaid medical care organizations other than those controlled by the defendants from furnishing prepaid medical care in Oregon). For a summary of medieal society re-

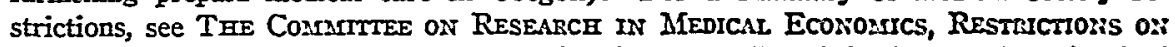
Free ENTERPRise IN MiEdictire 9-14 (1949). And for a list of the 22 state laws inspired by the local medical societies which prevent anyone but physicians from forming medical care plans, see id. at 4-8.

At its last convention the AMIA somewhat liberalized its previous restrictions, which required approval of lay-sponsored plans by the national body, allowing loeal medical 
These, however, are half-way measures at best. In the long run, basic needs can only be met by training more health care personnel in medical, dental and nursing schools. But a medical education costs more than any other professional training. ${ }^{28}$ And a dental or nursing education is likcwise extremely expensive. ${ }^{29}$ Students can pay, and universities can charge, only a small fraction of this cost. The remainder must come from endowments and tax sources. ${ }^{30}$ University officials testify emphatically that the cost of educating health care personnel precludes expansion under private auspices. $^{31}$

societies to pass upon them. But the criteria by which they are to be judged are still highly restrictive: the method of payment must still comply with the AMA Code of Ethics on contract practice, and any qualified doctor must be permitted to participate in them. See N.Y. Times, June 10, 1949, p. 16, cols. 3-5 (especially points 11 and 12 of the 20-point principles) ; N.Y. Times, June 10, 1949, p. 1, col. 6. But only recently the AMA House of Delegates modified even this limited liberalization by requiring that both the state and county societies approve lay-sponsored plans. It now also requires that approval be based on "'past performance of not less than a year," rather than future performance- "a condition which could [sic] operate against approval of any new plan." N.Y. Herald Tribune, Dec. 7, 1949, p. 1, col. 3, p. 31, cols. 1-3; N. Y. Herald Tribune, Dec. 9,1949 , p. 1 , col. 6 , p. 36 , cols. $6-7$.

For a readable and discerning account of the AMA's policies on voluntary insurance and the Administration bill, see Meyer, The Dogged Retreat of the Doctors, Huni'ERS, Dec., 1949, p. 25 ; and see note 63, infra.

28. See, e.g., testimony of Mr. Joseph C. Hinsey, Chairman, Executive Coutncil, Association of American Medical Colleges, Hearings before a Subcommittec of the Commiltce on Labor and Public Welfare on S. 1106, S. 1456, S. 1581, and S. 1679, 81st Cong, 1st Sess. 631, 632-3 (1949). Mr. Hinsey estimated that the average cost per student per year is about $\$ 2,200$, with a range from $\$ 735$ to $\$ 5,000$. Id. at 632 . The Chancellor of the University of Nebraska, representing the Association of American Universities, estimated that a child could be sent from kindergarten through high school for just what it costs to send one student to medical school for one year. Id. at 714. And see Roemes', The Costs of a Medical Education, 14 The Diplomate of the National. Bonkd of Medical ExaMiners 265 (1942).

29. Dr. Leonard A. Scheele, Surgeon-General, United States Public Health Scrvice, testified that in the schools of dentistry the average annual cost per student approximates $\$ 2,000$. Hearings before a Subcommittee of the Committee on Labor and Public Welfarc on S. 1106, S. 1456, S. 1581 and S. 1679, 81st Cong., 1st Sess. 621, 625 (1949). A nursing education costs about half that amount. Testimony of Mrs. Eugenia K. Spalding, on behalf of the American Nurses Association and the National League of Nursing Education, id. at $693,701$.

30. Dr. Harvey B. Stone, testifying for the Council on Hospitals and Medical Education, told of a recent study by the Council which revealed that student fees provide only 25 per cent of the total funds needed to operate the nation's medical schools. Id. at 646, 647 . Of the total national medical school budget of $\$ 51,000,000, \$ 12,800,000$ is derived from student fees, $\$ 20,700,000$ from endowment income, gifts, and general university funds for deficit financing, and $\$ 17,500,000$ from tax sources. Testimony of $\mathrm{Mr}$. Joscph $\mathrm{C}$. Hinsey, id. at 631,632 .

31. See, generally, the testimony of a long list of experts, id. at 621-718. 
This means government subsidies. To enable the schools to operate on a solvent basis, $\$ 150$ to $\$ 350$ per term should be appropriated for each student up to the number enrolled. In addition, if schools are to expand their enrollments, $\$ 1700$ to $\$ 2400$ must be appropriated for each additional student. $^{32}$ These appropriations would still leave students to bear the burden of tuition and maintenance. With the near-exhaustion of GI educational benefits, failure to subsidize the student as well as the schools would exclude from the medical, dental and nursing profession a large number of highly qualified aspirants-a wasteful, as well as discriminatory, result. The principle of the GI bill, ${ }^{33}$ under which a subsistence allowance as well as tuition is paid to every veteran attending a recognized school, ${ }^{34}$ should be extended to non-veteran medical, dental and nursing students.

\section{Facilities}

Coordinate with the problem of shortages of personnel is the problem of shortages of facilities, notably hospitals. Approximately 4.5 to 5.5 general hospital beds per 1,000 persons are needed for adequate general hospital care. An additional 9.5 beds per 1,000 persons are needed to give adequate hospital care to individuals afflicted with tuberculosis, chronic disease and mental illness. ${ }^{35}$ Even ignoring the poor distribution of facilities over the

32. The Administration bill, $\$ 372$, proposes to appropriate a specified sum for each student up to the average number enrolled in the past in each school, plus an additional and higher amount for each student in excess of that average, for approved public or nonprofit medical, dental, nursing, dental hygiene, public health or sanitary engincering schools. The sums proposed are:

School
Medicine
Dentistry
Dental Hygiene
Nursing
Public Health
Sanitary
Engineering

\begin{tabular}{cc}
\multicolumn{2}{c}{ Amusul Fedcral grant per } \\
student for enrollment- \\
Within & Bcyond \\
3-year average & 3-ycaraicrage \\
$\$ 300$ & $\$ 1,700$ \\
250 & 1,300 \\
150 & 800 \\
200 & 1,200 \\
350 & 2,400 \\
200 & 1,200
\end{tabular}

The Administration bill, $\$ 373(\mathrm{a})$, also authorizes grants for construction and equipment up to 50 per cent of the cost.

The Flanders-Ives bill, Title VII, Pt. E, proposes similar, but generally lower, payments to medical and nursing schools only; and the Taft bill, Title VI, Pt. B, proposes appropriations for medical schools only.

33. 57 STAT. 624 (1945), 38 U.S.C. p. 4269 (1946).

34. The Administration bill, $\$ 377$, only authorizes grants to states for scholarships.

35. Testimony of Dr. Leonard A. Scheele, Surgeon-General, United States Public Health Service, Hearings before a Subcommittee of the Committee on Labor and Public Welfare on $S .205, S$. 614, Title III of $S .1679$ and Title IV of S. 15S1, 81st Cong., 1st Sess. 11, 16 (1949) ; standards set by the Hospital Survey and Construction Act, 60 SrAT. 1041, 42 U.S.C. $\$ 291$ e (1946) ; LEE \& JONES, op. cit. supra note 20, at 119. 
nation, ${ }^{36}$ total needs are only half realized: 880,000 acceptable beds exist, and another 897,000 are needed. ${ }^{37}$

The total cost of building additional and necessary facilities would be between 10 and 11 billion dollars. ${ }^{38}$ Private hospital construction expenditures are insufficient. Even in the boom year of 1947 only one third of the total outlay for hospital construction came from private sources. ${ }^{30}$ In this aspect of health care the federal government has at least made a good start. The Hospital Survey and Construction Act of 1946 authorizes appropriations of $\$ 75,000,000$ a year to the states and localities for hospital construction..$^{40}$ With a growing population, these expenditures plus local and private outlays will succeed in meeting today's needs-in 1986.41 Vastly greater federal appropriations, larger state and local contributions, coupled with supplementary appropriations for areas of special need, are therefore necessary ${ }^{42}$ and in the near future-if the nation is ever to have fully adequate hospital facilities. ${ }^{43}$

36. For example, over the whole nation in 1942 general hospital beds averaged 3.5 per 1,000 persons, but by states the ratio varied from 1.6 in Mississippi to 5.5 in Massachusetts. Testimony of Dr. Thomas Parran, then Surgeon-General, United States Public Health Service, Hearings before the Committee on Education and Labor on S. 191, 79th Cong., 1st Sess. 53, 69 (1945).

37. Testimony of Dr. Leonard A. Scheele, Hearings before a Subcommittce of the Committee on Labor and Public Welfare on S. 205, S. 614, Title III of S. 1679 and Title IV of S. 1581, 81st Cong., 1st Sess. 11, 39, 66 (1949); and see Ewing, op. cit. supra note 19 , at 56.

38. These estimates are based on the figure of $\$ 12,000$ a bed, the average cost tnder the Hospital Survey and Construction Act, 60 STAT. 1041, 42 U.S.C. $\$ 291$ (1946). Test-mony of Dr. V. M. Hoge, Chief, Division of Hospital Facilities, United States Public Health Service, Hearings before a Subcommittee of the Committee on Labor and Public Welfare on S. 205, S. 614, Title III of S. 1679, and Title IV of S. 1581, 81st Cong., 1st Sess. 11, 37 (1949).

39. EwING, op. cit. supra note 19 , at 60 .

40. 60 STAT. 1041, 42 U.S.C. $\$ 291$ (1946).

41. EwING, op. cit. supra note 19, at 59.

42. The Administration bill, Title III, and a separate bill, S.614, 81st Cong., 1st Sess. (1949) (the Taft bill, Title IV is essentially similar) would increase fedcral participation in grants-in-aid to $\$ 150,000,000$ annually; and the federal contribution, instead of being fixed at a flat rate of $331 / 3$ per cent, would range upwards to 75 per cent, varying inversely with the average per capita income in the state. This last change will make it possible for the poor states to meet the federal contribution.

The Administration bill, $\S 402$, would also make special financial arrangements for rural and other shortage areas.

43. Even under the proposed amendments to the Hospital Survey and Construction Act, 60 STAx. 1041, 42 U.S.C. $\$ 291$ (1946), by 1955 only one quarter of the present needs would be met. Testimony of Dr. Leonard A. Scheele, Surgeon-General, United States Public Health Service, Hearings before a Subcommittee of the Committee on Labor and Public Welfare on S. 205, S. 614, Title III of S. 1679, and Title IV of S. 1581, 81st Cong., 1st Sess. 11, 33 (1949). 


\section{Creating Effective Demand: Three Criteria of an \\ ACCEPTABle Plan}

\section{Full Coverage through Automatic Eligibility}

Even if sufficient personnel and facilities became available, many persons could not purchase adequate health care. In 1940, for example, the American Medical Association conceded that over a period of years a family of average size with an income of $\$ 3,000$ or less would need some financial aid in meeting the costs of medical care for serious illness. At At today's inflated prices, $\$ 5,000$ is approximately equivalent to $\$ 3,000$ in 1940.40 Consequently even under the AMA's estimates, the 75 per cent of American families with incomes of less than $\$ 5,000^{40}$ will need some assistance in meeting the expenses of health care. Aggravating the situation is the fact that many individuals are unwilling to purchase the health care they need, although they are financially able to do so. A complete national health program must translate the needs of these people into effective demand so that increased numbers of personnel and augmented facilities may be fully utilized.

Meeting the objective of complete coverage does not logically require government subsidization of the cost of health care for everyone. Assistance might be restricted to those who cannot afford adequate care under some sort of a "means test," in which elegibility would depend upon the individual's financial resources. ${ }^{47}$ In practice, however, any plan relying on a means test would fail to meet the goal of over-all coverage. Where the test is employed, an individual qualifies for aid only when he shows present need for care. Eligibility must be redetermined for each subsequent illness. No provision is necessarily made for preventive care. Application of the test is restricted to the underprivileged, as a sort of charity. Furthermore, determination of need unavoidably involves extensive personal interrogation, and a penurious and patronizing aura surrounds the dispensation of benefits. Consequently, those who need aid would too often fail to apply for it, more often postpone application until need became urgent. 18

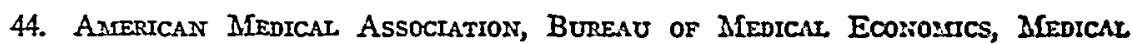
Services AND Econontc Status 91 (1939), reprinted in Fearings before a Subcommillec of the Committee on Labor and Public Welfare on S. 545 and S. 1320, 80th Cong., 1st Sess. 332 (1947).

45. See 35 FED. REs. BuLc. 72 (1949).

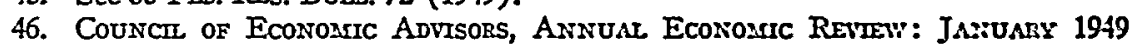
(H.R Doc. No. 36, 81st Cong., 1st Sess.) 93 (1949).

47. The controversy over a national health plan has, to a large extent, revolved around this issue. See, e.g., Hearings before a Subcommiltee of the Commillec on Labor and Public Welfare ont S. 545 and S. 1320, 80th Cong., 1st Sess. 69, 304-5, 974 (1947).

48. "[A means test] is based on application for aid-the very thing the self-respecting citizen tries to avoid if he can help it. It implies that the applicant and his family have to exhaust most, if not all, of their own resources before they can be accepted for a service, that, in the final analysis, is a 'last resort.' Whether the mills of human lsind- 
Where voluntary prepayment care plans are used, a more acceptable type of means test could be devised. Individual contributions would vary with income. For example, they might be tied to the amount of federal income tax, and collected with it from those who choose to participate. Government subsidies would then make up the difference between individual contributions and the cost of operating the plan. In this case, the means test would be applied to rich and poor alike; it could be discreet and impersonal; and by adoption of the prepayment system eligibility would exist prior to need. ${ }^{40}$

But the very premise upon which the means test is based militates against its use. It assumes that persons who are able to pay for care should not be eligible for aid. In making this assumption it overlooks the fact that many people who can afford care would be unwilling to pay for it, and that they would even be unwilling to supplement government subsidies from their own resources. $^{50}$ In other areas where society has a great deal at stake, this assumption is not made. Thus, a free public education is considered so vital to enlightenment in a democratic society that every person is afforded an education, whether or not he can pay for it himself. Since good health is comparably crucial, every person should be accorded automatic eligibility for all the health care he needs, regardless of his ability to pay for it. Severance of the

ness flows in a broad gentle stream or merely trickles, charity-well intended as it isis not what the common man wants. .. The patient who needs and demands medical care but is declared ineligible for service at public expense finds neither help nor consolation in the knowledge that his resources, small as they may be, still exceed the limit set by the administration. Thus, restriction of public medical care to persons in need jeopardizes preventive action. It comes too late to prevent complications, serious illness, and chronic stages of sickness. It comes too late to make the most economic use of taxpayers' money." Goldmann, Public Medicar Care 180-81 (1945). See also Hicarings before a Subcommittee of the Conmittee on Labor and Public Welfare on S. 545 and S. 1320, 80th Cong., 1st Sess. 974 (1947); and Meriad, Relief aNd Social Secunity 593-6 (1946).

49. Both the Hill bill and the Flanders-Ives bill would use the means test to determine eligibility for subsidized voluntary insurance. The Hill bill would allow the states to decide upon the method by which eligibility for aid should be determined ( $\$ 712 a)$, and might therefore permit burdensome investigation of individual incomes and resources. The Flanders-Ives bill is at least an improvement on the theory of the Hill bill: it would require that the voluntary plan tax its member a fixed percentage of their income, and then be reimbursed for the remainder of the cost. $\$ 723 \mathrm{n}$.

50. See, e.g., experience gained in a special Department of Agriculture experiment conducted in six rural counties. The federal government appropriated one million dollar's to subsidize health insurance in these counties for 3 years. Family contributions were fixed at 6 per cent of net cash income (equivalent to 4 per cent of real income) and tho average contribution varied in the first year from $\$ 6$ in one county to $\$ 25$ in another. The government contribution to the total cost of the plan varied from 80 per cent in the first year to about 50 per cent in the last year. Fairly comprehensive services were offered, and public opinion was favorable. Yet in the first year only half of the total popun lation of the counties chose to participate, and even this proportion dropped in each succeeding year. For a brief description of this experiment, see MOTT \& ROEMER, op. cit. stipra note 19 , at $415-22$. 
connection between care and payment will largely remove the inhibitions which prevent the individual from seeking the health care he needs.

\section{Benefits and Balancing Supply with Demand}

Ideally, benefits provided by an acceptable plan should be as comprehensive as coverage. Complete care requires hospital treatment, general and specialist medical care at home or office, dental and home-nursing care, drugs and appliances, and roentgenological and laboratory services.51 But immediate realization of this goal will be impossible until shortages of personnel and facilities are corrected. ${ }^{52}$ Until that time, the total amount of benefits must be curtailed in one of two ways, either by denying some people any care or by denying all people certain less essential care. Limiting eligibility for benefits by narrowing coverage ignores the fact that need for health care is not confined to any particular group. Instead, benefits must be restricted to that care which is most vital, until an increase in supply permits a correlative expansion of benefits.

\section{Preserving High Standards of Care}

The present payment system for medical care assumes that hope of monetary reward induces high standards of care. Although achieving complete coverage and maximum benefits requires a change in the source and method of payment to professional personnel, standards of care need not suffer. The popularity which results in high income does not depend primarily upon the doctor's or dentist's skill. The patient does not have the knowledge to select health care personnel on the basis of the quality of care given. It is not success in the competitive market, but professional pride, the innate integrity of the scientist, desire to relieve suffering, and aspiration for the esteem of coworkers which produce high standards of care. ${ }^{ \pm 3}$

51. For a breakdown of these components of an adequate medical care program, see Goldacann, Public aledical Care 160 (1948).

52. For the exact shortage of doctors, see notes 20 and 21 supra; dentists, note 22 stcpra; nurses, note 23 supra; and hospitals, note 37 sipra.

Dental care poses the greatest problem, not only because of the shortage of dentists, but also because the backlog of unsatisfied need is so great. For example, the United States Public Health Service has estimated that to correct all accumulated dental defects in the population would require a force of over 443,000 dentists (more than sis times the present number) if the task were to be accomplished in one year. REPons of TIIE Conference on Dental Care for Chunden 16 (unpublished, 1945), cited in Alott \& RoEMrER, op. cit. sicpra note 19, at 513 n.4.

53. See, e.g., the Statement by Walton H. Hamilton (actually a partial dissent from the final report of the Committee on the Costs of Medical Care) in Cosnarrmes on tar Costs of Miedical Care, Miedical Care for the Axrertcan Prople 189, 194-5 (1933):

"Nor is the system of individual business enterprise fair to the practitioner. It gives him, if he is skillful or lucky, an opportunity to increase his practice, to extend his services, and to win a fair competence. . . . But it forces him to practice his profession under the arrangements of an alien trade, to make his services to some extent articles of 
There are, however, certain dangers in changing the method of payment. Like other entrepreneurs, doctors or dentists may attempt to maximize their income whatever the payment system adopted. If standard fee-schedules were used, health care personnel might increase income by decreasing the time spent with each patient, accepting too many patients, and/or giving unnecessary treatment. Payment on a per capita basis, while avoiding these possibilities, may encourage perfunctory care so long as doctors (in short supply) do not have to compete for patients. ${ }^{54}$ Any acceptable plan must incorporate safeguards designed to minimize these hazards of inadequate amount of service and overpayment to participating personnel.

\section{Inadeguate Proposals for Creating Effective Demand}

\section{Direct Subsidies to Needy Persons}

There are many ways by which needy persons could be given direct financial aid to enable them to purchase the health care they need. Aid might be confined to persons unable to pay for any health care; ${ }^{55}$ it might also be offered to those who could pay only a part of the cost. It might be financed wholly by the federal government or on a federal-state matching basis. ${ }^{50}$ The plan could be administered by federal, state or local governments alone, or by any combination of these. ${ }^{.7}$

merchandise, and to respond so far as his standards permit to the acquisitive incentives of business. He cannot do his work in a conscientious way and have his competence appraised and his performance judged by colleagues who are competent to judge. Insteal income, security, and advancement come to him-if they come at all-as the results of the expansion of a business and through the favor of a laity who do not possess rational standards of judgment. ... We cannot know for certain; but I suspect that, aside from the alleviation of suffering, the strongest impulse which moves the physician is the professional motive of winning the esteem of his fellows. And I am inclined to believe that the ordinary physician is an artist who esteems, far more highly than the dubious chance at wealth, a regular and an adequate income, the feeling of security, and freedom to devote himself in an uncompromising way to his calling. The medical profession has, from time out of mind, disclaimed the acquisitive motive. If it is to be true to its high calling, the interests of patients and of physicians alike demand that it be kept out of business."

54. For discussion of the advantages and disadvantages of capitation and fee-forservice, see American Public Health Association, Subcommittee on Medical Care, The Quality of Medical Care in a Health Program, 39 Ax. J. Pun. Henurri 898, 919-20 (1949), reprinted in Hearings before a Subcommittee of the Committec on Labor and Public Welfare on S. 1106, S. 1456, S. 1581 and S. 1679, 81st Cong., 1st Sess. 588, 605-6 (1949); and Mort \& RoEMrER, op. cit. supra note 19, at 533.

55. E.g., the Taft bill, $\S 211$, authorizes federal grants to assist the states in providing health care to "families and individuals unable to pay the whole cost thereof." (Emphasis added.)

56. E.g., the Taft bill, $\S \S 211,213$, appropriate sums of $\$ 150,000,000$ in the first year, $\$ 200,000,000$ in the second year, and $\$ 300,000,000$ in the next three succeeding years to be matched by the states in amounts varying from $331 / 3$ to 75 per cent, depending upon the relation between the state and national average per capita income.

57. E.g., under the Taft bill, $\$ \S 211,214$, the states would administer benefits and the 
But whatever method of financing and administration were used, making eligibility depend on need would require a means test and would result in incomplete coverage. Where aid is afforded only to persons who are unable to pay the whole cost of health care, those who can pay a part of the cost would be barred from receiving assistance. And even if the latter were subsidized to the extent of their ability to pay, many would still not part with the additional amount required for the purchase of adequate care.

\section{Voluntary Insurance}

Today about 50 million people carry hospitalization insurance, ${ }^{58}$ and 28 million carry surgical insurance. ${ }^{\text {} 9}$ Notwithstanding these comparatively large figures, insurance covers only an estimated 10 per cent of the total amount spent for health care in the United States. ${ }^{\text {co }}$ This discrepancy between the number of people enrolled in hospital and surgical insurance schemes and the relatively small percentage of total health care costs covered by insurance is attributable (1) to the fact that complete hospital and surgical costs together represent only one third of the total costs of health care needed by the individual $; 1$ and (2) to the fact that hospitalization insurance does not usually cover all the costs of hospitalization, nor does surgical insurance usually cover all surgical costs. ${ }^{62}$

state plan would not be subject to national regulations if the state met and lived up to the standards prescribed by the bill.

58. An accurate measure of enrollment for any kind of coverage is impossible because many persons belong to more than one plan. Goldarans, Volurrany Mfedicar. Cane INSURANCE 53 (1948). Thus the estimates vary from 45 to 56 million. See Klem \& Mickiever, Program Development In Voluntary Health Insurance, Soc. Sec. Bull, Nov., 1948, p. 7; testimony of Edward H. O'Conner, Mfanaging Director, Insurance Economics Society of America, Hearings before a Subcommittee of the Committec on Labor and Public Welfare on S. 1106, S. 1456, S. 1581 and S. 1679, 81st Cong., 1st Sess. 943, 952 (1949). About 32 million persons were enrolled in the Blue Cross plans in the United States on March 31, 1949. Testimony of Dr. Paul R. Hawley, Chief Exceutive Officer, Blue Cross-Blue Shield Commissions, id. at 332, 352.

59. Testimony of Edward H. O'Conner, Mranaging Director, Insurance Economics Society of America, id. at $943,952$.

60. Klem, Present Status of Volustary Health Insurance, unpublished paper presented at the annual convention of the American Public Health Association in New York: City on Oct. 26, 1949.

61. Twenty-one per cent of individual health care expenditures in 1947 mas for hospital care, 25 per cent for physicians' services. Dicknsons, THe Cost ard Quavitis: of Medical Care in the UnITEd States (American Mledical Association, Bureal of Medical Economic Research, Bulletin No. 66) 6 (1949). Professor Roemer estimates that about one half of the expenditure for physicians' services pays for surgical care. Communication to the Yale Law Journal from Prof. Mrilton I. Roemer, Dec. 19, 1949, in Yale Law Library.

62. "Prepayment medical care organizations vary considerably in the limitations placed on the amount of care they furnish. Some plans limit the total money value of the services provided during the year, or for a single illness. Others malie a separate charge for the first one or two office calls received in each illness, or for the first, or all, 
In part, opposition of organized medicine to prepayment of over-all medical costs may account for this small figure. ${ }^{63}$ But more significant, however, is the fact that the better risks-the young and the healthy-are slow to join a voluntary prepayment plan and quick to drop out. ${ }^{64}$ Because of their physical

home calls. Many plans exclude care for pre-existing conditions and for certain diseases. It is also quite common for plans to provide maternity benefits after a 10- or 12-month membership under a family contract. Almost all organizations providing hospital benefits limit the number of days of hospital care provided." KLEN, HoLlingswortu \& Miser, Medical and Hospital Services Provided under Prepayment Arrungearents: Trinity Hospital, Litrle Rocr, Arransas, 1941-42 (Federal Security Agency, Social Security Administration, Bureau of Research and Statistics, Memorandum No. 69) 12-13 (1948). For brief descriptions of the risks covered by a large number of voluntary plans in the United States, see KLEMr, Prepayment Mepical Care Ordonniza* Trons (Federal Security Agency, Social Security Board, Bureau of Research and Statis. tics, Memorandum No. 55) (1945).

63. For an excellent analysis of the restrictions imposed by the American Medical Association, see ,Comment, Group Health Plans: Some Legal and Economic Aspecls, 53 Y ALE L.J. 162, 175-82 (1943). For a description of the AMA's past and present tangles with the Department of Justice and the courts, see note 27 supra.

The present attitude of the AMA toward a national health program is at best ambiguous. Apparently the AMA favors the Taft bill. It has offered a 12-point plan which, when stripped of proposals upon which there is general agreement (c.g., more rescarch, more public health centers) calls for "[a]id through the States to the indigent and medically indigent by the utilization of voluntary hospitals and medical care plans. . . ." N.Y. Times, Feb. 14, 1949, p. 1, col. 2, p. 12, col. 5 .

But the energies of the AMA have been so directed as to cast some doubt upon the seriousness of even this limited proposal. A $\$ 25$ assessment was imposed upon each member primarily to defeat the Administration's plan, rather than to achicve the enactment of its own. 136 prominent AMA members refused to pay the assessment, charging that the AMA has proposed only "an indefinite and constructively inaclequate program" and that the money raised would be used for "propaganda and legislative lobbying." N.Y. Herald Tribune, Feb. 12, 1949, p. 1, col. 7, p. 22, cols. 3-4; N.Y. Times, Feb. 13, 1949, p. 54, col. 3. A similar letter was later signed by 167 leading doctors. N.Y. Times, Feb. 24, 1949, p. 20, col. 1. And see address of Fon. Wayne Morse in the United States Senate, 95 Conv. Rec. 4676-83 (April 14, 1949); Engel, The A.M.A.'s Shish Fund, 168 The NATTON 181-2 (1949).

The AMA answered the charges, contending that the funds would be used for the "education of the American people. . ." N.Y. Times, Feb. 19, 1949, p. 13, col. 1. This statement should be weighed against the content of two of the pamphlets financed by the assessment: American Medical Association, National Education Campaign, Tue Voluntary Way is The American Way ( WB P-1) 2-3 ("Q. Who is for Compulsory Health Insurance? A. . . A All who seriously believe in a Socinlistic State. Every leftwing organization in America. ... The Communist Party"); and ANERICAN MeptCrr. Assoctation, Nationat Education Campaign, Compulsory Healtei Insurance: Politically Controlled Medicine ( $\$$ WB 14) 3 ("National Compulsory Health Insurance constitutes the most dangerous step toward ultimate regimentation of the peoplo and tho creation of a despotic, Socialist State.").

Recently, the AMA has made contribution to this campaign obligatory, by instituting a \$25 per year membership fee. N.Y. Herald Tribune, Dec. 9, 1949, p. 1, col. 7, p. 36, cols. 6-7.

64. Goldamann, Prepayasent Plans for Medical Care 35 (1941); Canot, op. cit. stipra note 25 , at 205. 
well-being, the benefits which they receive are incommensurate with the charges they pay. As a result, in order to cover poor risks, cost must be high or the scope of services limited. Or alternatively, if costs are to be kept low and adequate benefits provided, membership must be confined to the better risks. In either event, those who are most in need of adequate care are denied

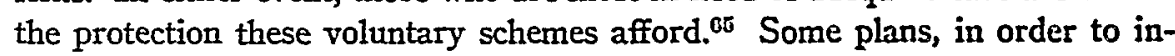
clude the lower income groups, have permitted doctors to impose extra charges upon members with incomes above a certain minimum. ${ }^{\mathrm{cs}}$ But this only drives the higher income groups away. ${ }^{67}$

Even if the per capita charges of voluntary prepayment plans were reduced by persuading good risks to join, many families would still be unable to participate. Approximately 30 per cent of American families have a total gross income of less than $\$ 2,000 .^{68}$ A family of four with an income of $\$ 2,000$ would have to allocate seven per cent of it to pay for the cheapest possible complete benefits. ${ }^{69}$ If a family's income fell below $\$ 2,000$, an even larger percentage would be required for medical care coverage. A voluntary expenditure of this kind is almost inconceivable. For this reason unsubsidized voluntary insurance cannot in the foreseeable future result in complete coverage.

\section{Subsidized Voluntary Insurance}

Two prominent proposals have been advanced to achieve complete coverage under voluntary insurance. Each involves some kind of government subsidy. One bill proposes grants-in-aid to the states to finance membership in voluntary insurance plans for persons who are "unable to pay all or part of the subscription charges of prepayment plans." The states in turn would then obtain partial reimbursement from those persons according to their ability to

65. "Voluntary plans are caught between the Scylla of prohibitive pre-pasment rates, supporting fairly complete service for the participants and adequate remuneration for those rendering care, and the Charybdis of low prepayment rates, covering very limited services and assuring the physicians and hospitals of reasonable payment." GoLdrunz:, Voluntary Miedical Care Insurance 194 (1948).

66. For a description of these voluntary plans, see Krear, Prepayare:ir Mleprear Care Organizations (Federal Security Agency, Social Security Board, Bureau of Research and Statistics, Memorandum No. 55) (1945). Generally, extra charges are made to persons whose income exceeds $\$ 2,000-3,000$. Testimony of Dr. E. J. AfeCormack, Chairman, Council on Medical Services, AMLA, Hearings before a Subeommittee of the Committee on Labor and Public W elfare on S. 545 and S. 1320, 80th Cong., 1st Sess. 105 (1947); and see id. at 207-S.

67. Sinat, Anderson \& Dollar, Healte Insurance 78 (1940); Humphrey, The Case for Compulsory Health Insurance, N.Y. Times Mfagazine, $1 f_{3 y} 8,1949, \mathrm{pp} .15,53$.

68. Councin of Econosic Aovisors, op. cit. supra note 46, at 93.

69. This figure is based on the estimates of the initial cost of the Administration bill. It assumes an expenditure of $\$ 35$ per person, or $\$ 140$ for a family of four, will provide a proportional share of the care existing personnel and facilities could give the whole population. It does not approximate the cost of fully adequate care. See pp. 312-13 infro. 
pay. ${ }^{70}$ The other bill proposes that the voluntary insurance agency charge the subscriber a fixed percentage of his income; the states, with funds obtained through matching grants-in-aid, would then reimburse the plan to the extent of the difference between the charge to the subscriber and the "allowed cost" fixed by the state agency. ${ }^{71}$

None of these proposals is completely satisfactory. All involve some kind of a means test. Consequently, complete coverage would be precluded. ${ }^{72}$ Moreover, as long as supply is. inadequate, permitting voluntary insurance organizations to compete in a free market for the services of health care personnel would soon send costs sky-rocketing. Either subsidies would have to be increased, with too great cost to the government, and too great incomes to personnel, or there would be a decreased amount of coverage. Therefore even under subsidized voluntary insurance the government would have to regulate remuneration to doctors, dentists and nurses. In addition, the government would have to limit the number of patients which professional personnel could treat, or services they could give, in order to preserve high standards of care. Performance by the government of these two vital functions would reduce voluntary insurance agencies to mere superfluous conduits for the transfer of payments to professional personnel.

\section{Nationat Health Service}

Only national health service ${ }^{73}$ would make it possible to satisfy the objectives of complete coverage, maximum available benefits and high standards of care. It differs from all legislative proposals advanced to solve the national

70. Hill bill, $\S \S 713$ (a) 13, 713 (a) 17 .

71. Flanders-Ives bill, $\S 723$.

72. See note 48 supra. Lack of foresight-inexperienced gambler's faith that illness will be infrequent and mild-would discourage those who would have to bear a sizeable portion of the costs themselves from participating in a subsidized voluntary prepayment plan.

73. The term "national health service" is used to describe the proposal set forth below because it does not follow the Administrations's National Health Insurance bill in respect to the method of financing. See note 101 infra. The term is derived from the British National Health Service Act, 1946, 9 \& 10 GEo. VI, c. 81, which it closely resembles. That act is an extension of the more limited health provisions enacted in 1911, which authorized general practitioner service for wage-earners within defined income limits. Healte Services in Great Britain (British Information Service, I.D. No. 753 rev.) 5 (1948). The new Act, with a very few exceptions, provides free care of every kind to every resident of Britain.

Every individual who wishes to participate in the service chooses a general practitioner. About 90 per cent of the population have joined the plan. Health care personnd are free to participate or not, as they choose; about 80 per cent of the doctors have joined the service. Doctors and dentists are also free to reject any patient. Payment to tho general practitioner is either per capita, salary, or a combination of these; fee-for-service is used for dentists. The method of payment to specialists is still unsettled.

The cost of the service is more than was originally planned, amounting to $\$ 221,000,000$ ( $\$ 885,884,000$ before devaluation) the first year, or approximately $\$ 20$ per capita. Eighty- 
health problem. Varying from the Administration bill in only one major respect, ${ }^{74}$ it departs from all other proposals in the way problems of coverage and benefits would be handled; the basis on which personnel and facilities would participate; how much the plan would cost; how it would be financed; and in what manner administrative functions would be divided between federal, state and local levels.

\section{Coverage, Benefits and Professional Participation}

National health service would most closely approximate the major objectives of an ideal health plan. Over-all coverage would be effected through automatic eligibility; complete care would be encouraged by severing all connection between care and payment for it $;^{\mathbf{7 5}}$ and a well-balanced relationship

five per cent of the cost is financed from the general revenues, the remainder from insurance contributions. For factual information of the operation of the British plan, see Davis, The British National Health Service, 64 Pub. HeAltm Rep. 161 (1941); MicNickle, The British National Health Service, 1 Editorial Research Reports 23 (1949); Healix SERVICES IN Great Britain (British Information Service, I.D. No. 753) (1949); N.Y. Herald Tribune, Feb. 11, 1949, p. 17, col. 3. For the most recent description of the plans of other nations, see Mountain \& Perrott, Hcalth Insurance Programs and Plans of Wcstern Europe, 62 PUB. HeAltr REP. 369 (1947). And see Goldmann, Forcign Programs of Iledical Care and Their Lessons, 234 NEw ENG. MIED. J. 155 (1946).

Most students of the British plan agree that because the plan has been in operation only a little more than one year only tentative judgment is possible. See, c.g., Davis, supra, at 161. In attempting to judge the plan, a few have been critical. See, c.g., the special issue of the ANERICAN DRUGGist, July, 1949. Other views are mixed, generally accepting the principle of the plan but criticizing some of its provisions and some aspects of its operation. See, e.g., the views of anonymous British experts in a special issue of The Practitroner, Autumn, 1949; visiting British doctors, N.Y. Times, Oct. 28, 1949, p. 11, col. 1; and a series of articles in 255 THE LANCET 739, 823, 903 (1948) and 256 The LANCET 158 (1949). Particular difficulties aside, one observer was highly laudatory. Vandercook, Good Newes Out of England, Harpers, March, 1949, pp. 4\&-52 ("The most intense enthusiasm, all but un-British in its articulateness, is reserved for the last, latest, and greatest experiment of democratic socialism, the National Health Service. . . . A new energy, a new quality of energy, has been released.").

74. The Administration bill, which proposes a payroll tax (see note 101 infra), would cover only 85 per cent of the population. Hearings before a Subcommillec of thic Committee on Labor and Public Welfare on S. 1106, S. 1456, S. 1581 and S. 1679, 81st Cong., 1st Sess. 165 (1949). Every individual, along with his dependents, would be automatically eligible under $S .1679$ only if he were a recipient of old-age or survivors insurance benefits, or if he earned more than $\$ 180$ a year for services in the course of certain listed kinds of employment (including self-employment) within the United States. Administration bill, $\$ \S 704,781$.

75. The Administration bill does not authorize all of the necessary components of adequate health care. E.g., hospitalization is limited to 60 days; drugs are limited to those which are prescribed and are "unusually expensive"; and all auviliary services (all services except general medical and dental services, specialist medical or dental services, and hospitalization) are limited to those found by the national administrative authority to be "practicable and ... essential to good health." Administration bill, $\$ 701$. 
between supply and demand would be obtained by controls upon the kinds of care publicly financed. ${ }^{76}$

This plan would insure reasonably complete freedom to both doctor and patient. Every qualified doctor or dentist would have the right to give benefits under the plan, as well as the privilege of refusing to accept any prospective patient for treatment. ${ }^{77}$ Similarly, every person would have the right to choose his own doctor or dentist ${ }^{78}$ but specialist, hospital, home-nursing and auxiliary care would be had only upon referral by a general medical or dental practitioner. ${ }^{79}$

Doctors would also be permitted to select their own method of payment. They could choose to be paid according to the number of services performed, according to the number of patients on their "list," or on a salary basis.80 All of these methods involve certain dangers, but the dangers can be checked.

Under fee-for-service-which initially would seem likely to command the most support-doctors might give patients unnecessary treatment in order to increase their income. This danger could be partially overcome by use of the prorated fee-for-service device. ${ }^{81}$ A set sum is allocated for payment to all doctors for a certain period; the doctor then charges the fund according to the number of services he has performed. If the total charges exceed the amount allocated, fees are scaled down proportionally. Even under this system the doctor might still give unnecessary care, and thus decrease the just remuneration of his colleagues. And if charges were prorated down considerably, doctors would probably exert strong pressure to increase the total allotment. But abuse by a few doctors might be corrected by the social pressure of their colleagues. And increased cost brought about by pressure for

76. The Administration bill, $\$ 702$, provides that services "shall be made available as benefits ... as rapidly and as completely as possible having regard for the availability of the professional and technical personnel and the hospital and other facilities needed to provide services." It permits the national administrative authority, after a finding that "personnel or facilities or funds that are or can be made available are inadequate to insure the provision of dental, home-nursing or auxiliary services," to "limit for a specified period the services which may be provided as benefits, or modify the extent to which, or the circumstances under which, they will be provided. . .."

77. Administration bill, $\$ 720$ (c). To the extent that professional personncl abstain from participation in the plan, some health services will go to the highest bidders rather than to those most in need. But the only alternative, a "draft" of personnel, deserves no consideration whatsoever.

78. Administration bill, $\S 703$.

79. Ibid.

80. Administration bill, $\S 718$. Whether out of habit or preference, most doctors would almost certainly choose fee-for-service. For the experience of the Farm Sccurity Administration affirming this proposition, see MOTT \& ROEMER, op. cit. supra note 19, at $400,417$.

81. Administration bill, $\$ 718$, which permits the choice of fee-for-service, shoutd be amended to allow only the prorated fee-for-service method. But even under the present bill prorated fee-for-service might be permissible. 
larger allotments might be justified by increased care. Furthermore, while there is a shortage of doctors the temptation to give unnecessary treatment will probably be insignificant, due to a large bona fide demand.

As the supply of personnel increases, the capitation or salary method of payment could be encouraged, possibly through average incomes higher than average incomes from fee-for-service. ${ }^{82}$ The principal danger with either of these two methods is that an assured income may lead to neglect of patients.

When a sufficient number of doctors are trained, free choice by the patient will act as a brake on neglect in the per capita scheme. While the patient may not be able to judge the quality of a given amount of care, he is at least a better judge of its quantitative adequacy. And if limits were placed on the number of patients which a doctor could have on his "list," 83 the possibility that a doctor will accept so many patients that he cannot give an adequate amount of care will be eliminated. As for salary payment, complaint by patients and supervision by administrators should keep neglect under control.

Long-range development should be directed toward salaried group practice. In group practice, doctors and specialists are relieved of routine duties by lay administrators. They pool their skills in order to give up-to-date care at low cost.84 Payment by salary provides doctors with a regular and assured income. It permits them to allocate periods for study and vacation. Above all, assured salaries would eliminate business considerations from nonresearch medicine and return it to the fold of the sciences. ${ }^{85}$

Under any of these payment systems, annual incomes of participating personnel would depend initially upon the division of the total sums available among the classes of health personnel, ${ }^{80}$ and the division among the states of the sums allotted to each class. ${ }^{\text {st }}$ This division must be further subdivided

82. But compare the Administration bill, $\$ 719(\mathrm{~b})$, which requires that reasonably equivalent rewards result for different methods.

83. Administration bill, $\$ 719$ (c).

84. See note 25 supra.

85. "A desirable feature of group practice is that it lends itself readily to the salary" method of paying physicians for their services. For many reasons a salary basis of payment is preferable to any other known method. It can take training, esperience, responsibility and general competence into account as no other method can. Prospects for advancement in income, position, and prestige furnish incentives for thorough and diligent work. ...

". . . It is surprising that medicine should be so far behind the rest of our cconomic society in recognizing [that salaries represent the most sensible way to pay for medical services]. The usual objections to medical salaries, as destructive of initiative and leading to a deterioration of the quality of medical service, are simply not borne out by the experience of our greatest teaching medical centers or the achievements of the medical department of our armed forces." MIOTT \& RoEMIER, op. cit. supra note 19, at 532-3.

86. Administration bill, $\$ 772(a)$. The bill does not provide any criteria for discharging this duty.

87. The Administration bill, $\S 772(\mathrm{~b})$, provides that the national administrative authority shall allocate the total funds available for each class of health care personncl 
to determine appropriate payment to individuals within each class according to criteria which can be objectively determined. While their relative weight should be established by competent experts, these criteria should include age, experience, responsibility, skill and professional qualifications. ${ }^{88}$ In no case should the lowest income which results from application of these standards fall below a minimum standard of living. The preservation of income differentials should provide sufficient reward for incentive under any of the payment schemes.

\section{Cost}

The cost of national health service for the early years must be computed on the basis of current remuneration of personnel and facilities with corrections for increased utilization. ${ }^{80}$ The most reliable estimates were originally prepared by the Social Security Administration in 1946.00 After correction for recently inflated prices, the following annual costs were predicted :01

among the states according to (1) the population of each state; (2) the supply of personnel and facilities in each state; and (3) the cost of "reasonable and equitable" compensation to personnel and facilities. Presumably the latter criterion would depend primarily upon the cost-of-living index in the state.

88. American Public Health Association, Subcommittee on Medical Care, supra note 54, at 920-21; Administration bill, $\$ 719$ (a).

89. Opponents of the Administration bill, in estimating cost, have frequently multiplied the total estimated needs of the population by the remuneration which personnel and facilities would receive for this care at present rates. While this method may be valid for determination of costs in the future, when shortages no longer exist, it is not an accurate measure of initial cost, because it fails to take shortages into account. If expenditures were actually made on this basis, only swollen incomes to participating personncl, without correlative increases in care, would result. See, generally, Soure, THE Cost of HEALTit InsuRANCE 9-11 (1949). For example, one critic estimated total costs of $\$ 65$ per capita (almost $\$ 10$ billion for the whole population). A component of this sum was a $\$ 15$ per capita annual bill for dental services. Such an expenditure would bring dentists' average gross annual income to more than $\$ 29,000$, an estimated $200-300$ per cent over present earnings. Soule, op. cit. supra, at 10. For this and other related fallacies see WILSON, COMPULSORY HEALTH INSURANCE 77-82 (1947).

90. Soctal Security Board, Bureau of Research and Statistics, Medical Care Insurance-A Soctal Insurance Program for Personal. Healti Services (Report to the Committee on Education and Labor, Senate Committee Reprint No. 5, 79th Cong, 1st Sess.) 49-61, 79-89, 101-3, 118-9, 128-9, 145-50 (1949).

91. Federal Securtity Agency, Social Security Administration, Division of Researce and Statistics, Estimate of Expenditures for a National Healtit InSURANCE PROGRAM in Hearings before a Subcommittee of the Committee on Labor ant Public Welfare on S.1106, S. 1456, S.1581 and S.1679, 81st Cong., 1st Sess. 1191, 1194-5 (1949). The statistics given here do not include the FSA estimate of $\$ 13$ per capita for research and education. 


$\begin{array}{lrc} & \text { Per Capita } & \begin{array}{r}\text { I46 million per- } \\ \text { sons (in billions) }\end{array} \\ \text { Physicians' services } & \$ 18.34 & \$ 2.68 \\ \text { Hospital services } & 10.08 & 1.47 \\ \text { Dental care } & 3.78 & .55 \\ \text { Home nursing } & .64 & .09 \\ \text { Laboratory, medicines } & 3.84 & .56 \\ \quad \text { and appliances } & & \\ \text { Total } & \$ 36.68 & \$ 5.35\end{array}$

If probable expenditures by individuals for goods and services not covered by the Administration bill were added to these estimates, the probable cost of individual health services would total slightly more than $\$ 8$ billion. ${ }^{02}$ Since the nation now spends $\$ 7.2$ billion for personal health services, ${ }^{03}$ the total increased cost under national health service would be about $\$ 1$ billion. Adding another half billion dollars for building facilities and training personnelos makes a grand total increase over present expenditures of only seven-tenths of one per cent of the national income. Undoubtedly, this cost will increase with the supply of personnel and facilities. ${ }^{95}$ But presumably this increase

92. This rough estimate of the total cost for the early years under the Administration bill is reached as follows: In most cases, the FSA estimate of expenditures for various categories of services under the Administration bill is less than the present expenditures, either (1) because the category is not covered, or (2) because it is covered only partially, or (3) because it can be limited by administrative authorities. Wherever the present expenditures for services are greater than the estimates for the cost of those services to the government under the Administration bill, the excess, plus 25 per cent for increased utilization, is added to the estimated government expenditures to reach the probable total expenditure for that service. Thus, for all except physicians' services the FSA estimates of expenditures of the government are less than present expenditures. The total difference is $\$ 2.23$ billion. Adding 25 per cent to this figure for increased utilization brings it to $\$ 2.78$ billion, and adding that sum to the $\$ 5.35$ billion estimate of government espenditures makes a grand total of $\$ 8.13$ billion.

93. Soc. Sec. Bull., August, 1949, p. 9.

94. A scratch-paper estimate of the cost of subsidies to health care educational institutions under the Administration bill in the first year is $\$ 150,000,000$. (To reach the total cost for students presently enrolled, the proposed per capita payments were multiplied by the estimates of present enrollment for each category of students; to determine the cost of additional enrollment, the amount of the proposed subsidies for additional enrollment was multiplied by 10 per cent of the present enrollment in each category.) Subsistence payments of the same amount (although no grovision is made for these in the Administration bill) would bring the total education subsidy bill to $\$ 300,000,000$. This expenditure, plus a proposed increase in hospital construction grants of $\$ 75,000,000$, and a commensurate increase in state contributions, total $\$ 450,000,000$.

95. The FSA estimate for "195X" ("intended to show the probable costs when service [becomes] more comprehensive, some 5,10 , or 15 years after the program [begins]") is $\$ 48.85$ per capita, $\$ 7.13$ billion for the whole population (excluding the cost of rescarch 
would be but a small part of the future increase in per capita real income. ${ }^{00}$

\section{Financing}

These expenditures could be financed by the states alone; by the states with aid from the federal government; or by the federal government alone, either through a payroll tax on employees and employers or from the general revenues.

Two basic difficulties inhere in state financing, either with or without help) from the federal government. Many states do not have the financial resources which would enable them to finance a complete health plan, especially in the later stages when costs increase. ${ }^{97}$ Even if under a matching-grants system federal contributions were adjusted according to the wealth of the states, ${ }^{\text {ps }}$ many states would be greatly burdened. Furthermore, competition between states for business and industry probably forecloses the possibility of tax rates high enough to finance an adequate health plan. Finally, state financing would perpetuate diversity in health care. Wealthier states would continuc to attract an inordinate share of the national supply of personnel and facilities. ${ }^{99}$

While the plan might be financed by a payroll tax, ${ }^{100}$ at least three factors

and education). Federal Security Agency, Social Security Auministration, Di. viston of ResEARCH AND Statistics, op. cit. stupra note 91, at 1194-5. This is approximately a 35 per cent increase over present cost estimated by the FSA.

96. National income has increased at the rate of about 3 per cent a ycar (Secretary of Commerce Sawyer, N.Y. Herald Tribune, Dec. 6, 1949, p. 12, cols. 3-5), which com* pounded is about 35 per cent in 10 years. If this trend should continue, national income (now about \$224 billion, 35 FED. REs. BuLc. 1396 (1949) would increase more than $\$ 75$ billion in 10 years. The cost of all health care, if national health service were initiated now, might well reach $\$ 12$ billion in 10 years, an increase of about 100 per cent. But only 7 per cent of any increase in national productivity would be absorbed by those increased health care costs.

97. The greatest difficulty would be experienced by the eleven South Eastern states, which have an average per capita income of only 68 per cent of the national average (Mississippi is only 54 per cent). The seven Middle Eastern states have a per capita income which is 117 per cent of the national average (New York is 134 per cent). United States Department of Commerce, Bureau of Foreign and Domestic Commerce, Survey of Current Business, August, 1949, p. 12.

98. See, e.g., the Administration bill, $\$ 615(\mathrm{c})$.

99. For a summary of the disparities in health care facilities and personnel between the states and the close correlation between low per capita income in a state and inadequate personnel, see EwING, op. cit. supra note 19, at 65 .

100. The major arguments for a payroll tax are first, that the continuity of a health program should not depend on political cross-currents and Congressional economy drives, and second, that both a payroll tax and "insurance" have become accepted principles in the American scene, and therefore an "insurance" scheme is more attainable. Morr \& Roemer, Rurat Health and Medical Care 486 (1949). Implicit in this argument is the belief that payroll taxes will be less subject to such pressures than appropriations from the general revenues. This assumption is at least arguable. The second basic argument of those favoring the payroll tax certainly has a good deal of practical validity; it does, however, sacrifice to expediency the objective factors which favor financing from the general revenues. See subsequent discussion in text. 
outweigh the alleged advantages of this method.101 First, since contribution is usually a prerequisite to eligibility, ${ }^{102}$ full coverage would be very difficult to achieve. Charitable, religious and educational institutions seem politically immune from taxation, ${ }^{103}$ and it might be constitutionally impossible to tax state and local governments. ${ }^{10 x}$ Second, the payroll tax fails to meet the requirements of an anti-cyclical tax policy. It is a flat tax, imposed only on that part of income below a certain maximum-in the case of the Administration bill, all income below $\$ 4800{ }^{105}$ Such a regressive tax may be desirable in periods of inflation, since lower income groups spend a higher proportion of their income and a reduction of spending is the goal. But with

101. The Administration bill does not specify any method of financing; but reference to the payroll tax was evidently omitted in order to give jurisdiction of the bill to the Senate Committee on Labor and Public Welfare rather than the Senate Finance Committee. See PMI, Nov. 20, 1945, p. 6, col. 1 (identical maneuver with a predecessor bill).

But it is quite clear, from the method of financing, that a payroll tar is contemplated. A "Personal Health Service Account" is established, to which is appropriated 3 per cent of all wages earned every year, plus a sum of one-half of 1 per cent of all wages in the early years, 1 per cent later on. Administration bill, $\$ 771$. The bill then defines "wages" as income from any non-exempt employment below $\$ 4800$. Administration bill, $\S 781$.

Thus to finance the bill by a payroll tax, it would be necessary only to pass a bill to tax all employees and employers now non-exempt under the Administration bill, $\$ 781$. Probably, as in the proposed amendments to the Social Security Act, the income tax return would be used for payment of the tax by the self-employed, and domestics would use a stamp book in order to permit employer contributions. N.Y. Times, Jan. 30, 1949, p. 1, cols. 6-7.

102. Administration bill, $\$ \$ 704,705,781$ make ineligible persons with incomes from non-exempt employment under $\$ 180$ annually unless special contributions were made for them.

103. See, e.g., Ixr. REv. CoDE $\$ 101$ (charitable, religious and educational corporations exempt from income tax); I I T. REv. CODE $\$ 23(0) 2,5$ (deductions from individual gross income for contributions to charitable, religious and educational institutions); and see Note, 49 CoL. L. REv. 968, 969-\$2 (1949).

104. There is now no constitutional barrier to taxation by the federal government of salaries of state officials. Graves v. New York ex rel. O'Keefe, 306 U.S. 466 (1939), ererruling Collector v. Day, 11 Wall. 113 (U.S. 1870). The one, and probably the only, clear inference that may be drawn from Mr. Justice Frankiurter's opinion in New Yorl: v. United States, 326 U.S. 572 (1946) (the Saratoga Springs case), is that a tax on the state as a governmental entity may not be imposed by the federal government (Congress may not tax a source of revenue "uniquely capable of being earned only by a State. . ." Id. at 582). Although distinction between a tax "on" the employees and "on" the state appears to be "a nicety without a nice significance" ( $M$ Ir. Justice Franl-furter, dissenting in United States v. County of Allegheny, 322 U.S. 174, 195, 197 (1944)), the framers of the Administration bill have evidently deferred to the Court.

105. The Administration bill, $\$ 781$, evidently would tax all income from non-exempt employment up to $\$ 4800$ per year. Employers and employees would each pay $1 / 2$ percent per year. See note 101 supra. While the bill does not indicate what the rate of tax on self-employed persons would be, the Acting Federal Security Administrator recently suggested 21/4 per cent. Testimony of J. Donald Kingsley, Hearings before a Subcommittee of the Committee on Labor and Pablic Welfare on S.1106, S.1456, S.1581 and S.1679, 81st Cong., 1st Sess. 79, 102 (1949). 
unemployment, a regressive tax is a bad tax. ${ }^{106}$ Finally, Congress has shown a noticeable reluctance to raise payroll taxes once they are set. ${ }^{107}$ Hence, if the scale of the program is tied to payroll tax revenues, increased facilities and personnel would not be quickly absorbed through increased demand.

Financing the plan from the general revenues avoids all of these difficulties. The financial resources of the federal government are vastly greater than those of the states. Relative supply of personnel and facilities among the states could easily be taken into consideration at frequent intervals in allocating monies among them. If eligibility were not tied to contribution, coverage could easily be complete. Since the general revenues of the federal government are garnered primarily through graduated income taxes, the financing of the plan would not interfere with an anti-cyclical tax program. And Congress is more likely to increase appropriations for health care which draw on the general revenues than it would those based on payroll taxes. An increase in graduated income taxes does not have the same economic impact on the majority of voters. Finally, financing by the federal government through the progressive income tax honors the principle that individual contributions for essential government services should be based upon ability to pay.

\section{Division of Function between the National, State and Local Governments}

While the precise boundary of authority between each political unit cannot be drawn, two basic considerations should govern the allocation of administrative responsibility between the national, state and local governmental levels. In order to encourage local interest, large discretionary powers should be allowed to local government. Nevertheless, regulatory powers should be given the federal government to protect its financial interest, secure equitable distribution of personnel and facilities over the nation, and to insure that the basic objectives of the plan are effectuated. In general, the Administration bill balances these considerations nicely, and the methods proposed there should be adopted.

The states would play a vital role in the initial stages of the scheme. They would submit plans of operation which the national authority would have to approve if they met certain basic requirements. ${ }^{108}$ The state authorities would

106. Harris, The Economics of Social Security 69-96 (1941).

107. In its original form, the Social Security Act provided for payroll taxes on $\mathrm{cm}$ ployers and employees of 1 per cent in the calendar years 1937-39, 13/2 per cent 1940-42, 2 per cent 1943-45, 2I/2 per cent 1946-48, and 3 per cent thereafter. 46 STAT. 636 (1935). For the history of the long series of amendments in which the evil day for increasing tho taxes above 1 per cent was postponed, see 26 U.S.C.A. pp. 59, 63-4 (1948). For the present provisions, see 61 STAT. 793 (1947), 26 U.S.C.A. $\$ \$ 1400,1401$ (Supp. 1948). However, the rate did increase to $11 / 2$ per cent on Jan. 1, 1950.

108. The requirements of an acceptable state plan prescribed by the Administration bill, $\$ 742$, are (1) a survey by the state of its needs and resources; (2) a single agency to administer the provisions of the bill; (3) a state advisory committee, with a majority of 
always be responsible ${ }^{109}$ for making agreements with care personnel, hospitals, and other organizations for the provision of benefits; $; 10$ for determining methods of payment;111 and for setting rates of payment to participating personnel and facilities within the limits imposed by their allotments. ${ }^{112}$

The local administrative authorities would be responsible for the operation of the plan, performing the duties which arise from actual contact with persons providing and receiving benefits. ${ }^{113}$ They would publish lists of persons who have agreed to provide services, promulgate information to those who desire to give and receive benefits, insure that benefits are provided as agreed upon, and adjust complaints concerning the administration of the plan.114 They would also set maximum limits upon the number of persons participating personnel could have on their "lists," or services they might give.116 Finally, the state authority could delegate additional duties to them.110

consumer representatives; (4) the establishment of local health arcas and administrations; (5) a decentralized, efficient plan of administration, including a merit system; (6) maximum ise of health care facilities and personnel, over-all availability of benefits, and correction of the maldistribution of personnel and facilities as quickly as possible; (7) reports to the national administration; ( 8 ) the safeguarding of federal funds; and (9) cooperation with other state and local agencies concerned with related problems.

109. Benefits are to be administered by the states "wherever possible" Administration bill, $\$ 741$.

110. Administration bill, $\S \S 715,716$. The state may terminate these agreements after investigation, notice and hearing if it is found that the agreement has been breached, or that the person or organization is no longer qualified to provide benefits. Provision is also made for judicial review. Administration bill, $\$ 717$; id., Part G.

111. Administration bill, \$718. And see pp. 310-11 supra.

112. The Administration bill does not make clear whether the power to set rates or payment is conferred upon state or local authorities. Since the states malie agreements with persons desiring to provide benefits, and since the sections of the bill dealing with method and amounts of payment speak in terms of agreements (see $\$ \$ 718,719$ ), it would appear that the state agency would be responsible for this matter. However, Senator Miurray, in reply to a query concerning the administration of rates of payment, said: "Rates of payment to be determined by agreement between practitioners and local board subject to state approval or between practitioners and state directly depending on individual state plans Stop See Section [715] Section [732] Section [742A5]." Telegram to the Yale Law Journar from Senator James E. Mfurray, March 11, 1949, in Yale Library. But none of these cited sections clearly supports Senator Mfurray's vicw. To avoid confusion, the responsibility ought definitely to be given the states, with the power to delegate it to the local authorities.

113. "In order that personal health-service benefits may be made available promptly and in a manner best adapted to local practices, conditions and needs, responsibility for administration of benefits ... in the local health-service areas shall be decentralized as fully as practicable to local administrative committees or local administrative offcers. ..." Administration bill, $\$ 731$.

114. Administration bill, $\$ 732$.

115. Administration bill, $\S 719$ (c), provides for "[m]aximum limits upon the number of eligible individuals with respect to whom any person may undertale to render services. ..." This would seem to authorize limitation whether the method of payment is fee-for-service or per capita (i.e., limits either on persons or services).

116. Administration bill, $\$ 732(\mathrm{e})$. 
The primary duty of the national administration would be to allocate the total funds available among the states. While this allocation should depend essentially upon population, it should also take into account the supply of personnel and facilities in each state, and the cost of equitable compensation. ${ }^{117}$

If the national government has the responsibility for financing the plan, the national administrative authority must have the concomitant power to insure that funds are spent for the purposes enumerated by Congress. In cases of failure by a state to comply with the requirements of the act or with regulations issued by the national authority pursuant to the act, the national administration should have the power to disapprove the state plan, and to assume direct administrative control in the state if corrective measures are not taken. ${ }^{118}$

The power to allocate funds, and the power to assume direct control in the states in case of substantial breach of a state agreement, might in themselves insure complete coverage, maximum benefits and high standards of care. But it might also be necessary to give the national authority some direct control over the amount of remuneration to personnel and facilities, in order that available funds provide an equal and adequate amount of care for all. This might be achieved by permitting the national authority either to establish maximum and minimum rates of payment to different classes of personnel and facilities, ${ }^{110}$ or to set maximum limits on the number of patients a doctor might have on his "list" or the number and kind of services he might give. ${ }^{120}$

\section{CONCLUSION}

Only a national health service plan shows promise of achieving adequate medical care in the foreseeable future. Its initiation and development would not be unaccompanied by difficulties. It would be hard to eliminate all the

117. See text and notes p. 311 sipra.

118. Administration bill, $\$ 742(c),(d),(e),(f)$. These powers of the national atthority over the states are not unprecedented. E.g., where the Social Security Act allthorizes federal grants for state administration, the Federal Security Administrator is empowered to suspend the grants where a state does not live up to the standards and requirements of the Act. 49 STAT. 620 (1935), as amended, 53 Stat. 1360 (1939), 42 U.S.C. $\S 302$ (1946) (grants-in-aid to the states for old-age assistance). The Social Security Act does not permit the national government to assume responsibility for administration of benefits in a delinquent state. However, this new device would seem to be highly desirable, especially if a payroll tax scheme is used. Otherwise, persons who had contributed would be deprived of the benefits guaranteed them.

119. Except in the case of maximum rates for hospital services ( $\$ 718(d))$, the Administration bill fails to make any such provision.

120. This power was given the national authority in the Administration bill which preceded S.1679. S.5, $\$ 219$ (c), 81st Cong., 1st Sess. (1949). To insure that too high payments are not made to personnel in a few local health-areas where the local administration fails to set reasonable limits, both this provision and the provision in the text accompanying note 119 , supra, should be added to the present Administration bill. 
abuses of payment procedures, and undoubtedly there would always be a residue of malingering. While administrative ingenuity would probably minimize these and similar problems eventually, administrative skills are not likely to spring forth full-grown.

But there are always defects in any forward step, in any change of existing arrangements. To reject an adequate health care program because of peripheral difficulties is to forget the far greater difficulties and inequities created by things as they are. It is to sacrifice vast prospective gains in general welfare, now long overdue. 